\title{
Kielisukulaistemme henkilönnimet
}

Ainiala, Terhi ja SaArikivi, Janne (toim.): Personal name systems in Finnic and beyond. Uralica Helsingiensia 12. Suomalais-Ugrilainen Seura, Helsinki 2017.

Suomalaisen nimistöntutkimuksen ilonaiheisiin on viime vuosina kuulunut Helsingin yliopiston tutkimushanke Suomalais-ugrilaiset henkilönnimisysteemit: esihistoriallisen nimenannon rekonstruktiointi ${ }^{1}$, jolle myönnettiin Suomen Akatemian rahoitus vuosiksi 2015-2019. Hankkeen tähänastisista tuloksista merkittävimpiä on joulukuussa 2017 julkaistu artikkelikokoelma Personal name systems in Finnic and beyond. Teoksen ovat toimittaneet hankkeen johtaja, dosentti Terhi Ainiala sekä suomalais-ugrilaisen kielentutkimuksen tuore vs. professori Janne Saarikivi.

Kokoelman sisältöä pohjustavassa johdantoartikkelissa toimittajat toteavat, että suomalaisugrilaisia henkilönnimijärjestelmiä on tutkittu verrattain vähän. Viime vuosikymmeninä nimistöntutkijoiden mielenkiinto on kohdistunut etupäässä paikannimiin, kun taas etenkin historiallinen henkilönnimitutkimus on pysähtynyt paikoilleen. Tämä on ollut valitettavaa, sillä uudet aineistot ja tutkimustulokset muun muassa folkloristiikan alalla mahdollistavat kielikuntamme henkilönnimistön juurten kuvaamisen yhä luotettavammin. Artikkelikokoelman tavoitteena onkin paikata näitä aukkoja.

Johdantoartikkelin lisäksi teos sisältää kymmenen tutkimusartikkelia. Näiden kirjoittajina on viisi hankkeen tutkijaa sekä viisi muuta alan asiantuntijaa Suomesta, Virosta ja Unkarista. Itämerensuomalaisista kielistä kokoelmassa ovat edustettuina suomi, karjala, vepsä sekä viro, ja kaukaisemmista sukukielistä saamen kielet, mari ja unkari. Kokoelman rakenne etenee siten, että ensin tarkastellaan suomea ja sen lähisukukieliä ja loppua kohden edetään kaukaisempiin kielisukulaisiin. Osa artikkeleista käsittelee koko tietyn kielen henkilönnimijärjestelmää, kun taas osassa tarkasteltavana on jokin henkilönnimistön osa, kuten sukunimet tai tietyn aikakauden nimet.

\section{Henkilönnimistä paikannimien avulla}

Kolmessa ensimmäisessä tutkimusartikkelissa itämerensuomalaisia henkilönnimisysteemejä käsitellään paikannimistön avulla. Janne Saarikivi (The spread of Finnic pre-Christian anthroponyms in toponyms) tarkastelee itämerensuomalaisten esikristillisten henkilönnimityyppien esiintymistä paikannimissä, Jaakko Raunamaa (Finnish medieval village names based on anthroponyms in the Castle Province of Raseborg) Raaseporin alueen kylännimiä ja Timo Rantakaulio (Personal name-based place names by Lake Lennus in Savitaipale) eteläkarjalaisen Lennusjärven lähistön paikannimistöä.

Saarikiven tavoitteena on hahmotella aluetta, jolla itämerensuomalaisia kieliä puhuttiin kristillistymisen kynnyksellä. Tavoitteen saavuttamiseksi hän tarkastelee itämerensuomessa yleisiksi tiedettyjen henkilönnimityyppien ${ }^{\star} I h a-,{ }^{\star} I k a ̈-,{ }^{\star}$ Kaipa-, ${ }^{\star}$ Leina-, ${ }^{\star}$ Lempi-, ${ }^{\star}$ Moni(kka)-, Uska- ja Vihti- levikkejä. Vertailukohtana esitetään Hiite-alkuisten nimien levikki.

1 Hankkeen kotisivut: http://blogs.helsinki.fi/personal-name-systems/ (viitattu 11.6.2018). 
Johtopäätöksinä Saarikivi esittää, että itämerensuomalaisten kielten puhuja-alue kristillistymisen kynnyksellä eroaa huomattavasti nykyisestä ja että itämerensuomi tuli Suomeen kahta reittiä, Laatokan Karjalasta itään ja Suomenlahden yli Varsinais-Suomeen.

Artikkeli on hyvin rajattu, tiivis ja selkeä. Pientä kritiikin aihetta kuitenkin antaa huolimattomuus lähteisiin viittaamisessa. Ainakin neljä tekstissä mainittua lähdeteosta puuttuu lähdeluettelosta kokonaan, minkä lisäksi niin leipätekstissä kuin lähdeluettelossa esiintyy useita väärï̈ vuosilukuja (esim. Mikkonen-Paikkala 2002 kolmesti). Näin internetaikana virheet eivät toki estä lukijaa löytämästä kyseisten teosten äärelle mutta häiritsevät silti lukukokemusta hieman.

Jaakko Raunamaa selvittää artikkelissaan, mistä keskiaikaisen Raaseporin linnaläänin kylännimissä esiintyvät henkilönnimet ovat saapuneet alueelle. Lisäksi hän arvioi kylien perustamisajankohtaa käytetyn nimistön perusteella. Raunamaan mukaan henkilönnimiin pohjaavat kylännimet ovat lähinnä keskiajan loppupuolelta ja vastineita niille löytyy etupäässä LounaisSuomesta mutta myös Pohjois-Virosta. Yleisimmät nimenantoryhmät Raaseporin linnaläänissä ovat tutkimuksen perusteella suomalais- ja kristillisperäiset henkilönnimet.

Pääosan artikkelista muodostavat yksityiskohtaiset, kattavasti lähteisiin viittaavat nimiartikkelit. Kuten Raunamaa huomauttaa, keskiajan henkilönnimistöä on Suomessa tutkittu hyvin vähän, lähinnä lähdeaineistojen rajallisuuden vuoksi. Tästä huolimatta Raunamaa onnistuu esittämään päätelmänsä vakuuttavasti ja ymmärrettävästi.

Siinä missä Raunamaa esittelee tutkimusalueensa nimistön kenties turhankin tiiviisti, on Timo Rantakaulion artikkeli kolmen Savitaipaleen kylän alueen paikannimistä löytyvistä henkilönnimistä hajanaisempi. Seudun vanhakantaisen, itäisten itämerensuomalaisten kielten piirteistä muistuttavan murteen ominaispiirteitä käsitellään tarkasti, mutta yksityiskohdat avautuvat englanninkielisestä tekstistä parhaiten alaa jo valmiiksi hyvin tuntevalle.

Rantakaulio on löytänyt paikannimistöstä runsaasti erityyppisiä henkilönnimiä, kuten liikanimiä, ortodoksisia ristimänimiä ja Ruotsin vallan aikaisia miesten nimiä. Havaintoja esittelevät runsaslukuiset nimiartikkelit eivät kuitenkaan ole yhtä selkeästi perusteltuja kuin Raunamaan artikkelissa. Kokonaiskuva tarkastellun alueen nimistöstä sekä se, mitä tutkimuksen tulokset kertovat henkilönnimistöstä laajemmin, jäävät valitettavasti erilaisten nimien listauksen varjoon.

\section{Itämerensuomalaisista henkilönnimistä}

Artikkelikokoelman seuraavat neljä artikkelia käsittelevät itämerensuomalaisia henkilönnimisysteemejä. Denis Kuzmin (Adaptation of Orthodox personal names in the Karelian language) ja Olga Karlova (Karjalaisten venäjännetyistä käännössukunimistä) tarkastelevat karjalaisia hypokorismeja, Irma Mullonen (The heritage of the Veps non-Christian onomasticon in southern Svir settlement names) esittelee vepsäläisiä asutusnimiin pohjaavia henkilönnimiä, ja Evar Saar (Forenames in 16th and 17th century southeastern Estonia) tutkii vanhaa etelävirolaista henkilönnimistöä.

Denis Kuzmin tarkastelee artikkelissaan ortodoksisten etunimien adaptaatiota karjalan kielessä. Kuzminin mukaan karjalaiset ovat vuosisatojen ajan kyenneet erinomaisesti omaksumaan kansainvälisiä kulttuurivaikutteita, mikä näkyy myös nimistössä. Ortodoksinen uskonto alkoi levitä Karjalaan 1200-luvun alkuvuosikymmeninä, ja karjalaiset ryhtyivät siitä lähtien 
ottamaan käyttöön kristillisiä etunimiä. Niiden pohjalta alettiin muodostaa karjalan fonologiaan ja morfologiaan mukautettuja hypokorismeja. Kuzminin artikkeli valottaa niitä vokaalien ja konsonanttien muutoksia, joita nimet ovat käyneet läpi.

Artikkelissa kerrotaan ehkä hieman turhankin perusteellisesti siitä, miten karjalaiset omaksuivat ortodoksisen uskon. Varsinainen analyysi koostuu eri kantanimien pohjalta muodostettujen hypokorismien listaamisesta sen mukaan, millaisia fonologisia muutoksia niissä on tapahtunut. Listat ovat laajoja, mikä lisää analyysin uskottavuutta. Nimimuotoja myös verrataan venäjän pohjoisten murteiden sekä karjalan eri varianttien nimimuotoihin.

Kuzminin artikkelissa osa kyrillisin aakkosin kirjoitetuista nimistä on jäänyt translitteroimatta latinalaisille aakkosille, mikä voi haitata kyrillisiä aakkosia taitamatonta lukijaa. Sama ongelma on myös Irma Mullosen vepsäläisiä henkilönnimiä käsittelevässä artikkelissa, jossa kyrillisiä aakkosia ei ole translitteroitu lainkaan. Siksi Mullosen analyysistä hyötyvätkin venäläisten nimien osalta oikeastaan vain ne, jotka tuntevat kyrilliset aakkoset.

Koska muinaisia vepsäläisiä henkilönnimiä ei ole kirjallisissa lähteissä, Mullonen on käyttänyt aineistonaan $-l\left(<^{*}-l a\right)$-loppuisia asutusnimiä ja niiden venäjänkielisiä vastineita. Niiden avulla hän on rekonstruoinut noin 30 vepsäläistä henkilönnimeä. Vaikka suomen -la-asutusnimien kanta on usein appellatiivi, vepsässä vastaavat ovat Mullosen mukaan henkilönnimikantaisia, minkä vuoksi ne sopivat tämäntyyppisen tutkimuksen aineistoksi. Suurin osa Mullosen rekonstruoimista nimistä on ei-kristillisiä, ja osa niistä on itämerensuomalaisia. Mukana on myös tyypillisesti pejoratiivisia lisänimen kaltaisia ilmauksia. Mullosen analyysi osoittaa, että vanha vepsäläinen henkilönnimisysteemi on suurelta osin samankaltainen kuin muiden itämerensuomalaisten kielten ja siten sitä voi pitää kiinteänä osana itämerensuomalaista nimijärjestelmää.

Olga Karlova käsittelee artikkelissaan Venäjän karjalaisten sukunimiä, jotka on käännetty karjalasta venäjäksi. Nämä nimet perustuvat karjalankielisiin epävirallisiin lisänimiin. Karlova jakaa nimet antoperusteiltaan kahteen pääluokkaan, eläinaiheisiin ja muihin. Eläinaiheiset ovat näistä selvästi yleisempiä, ja varsinkin eri lintulajien nimet esiintyvät aineistossa taajaan.

Etenkin eläinaiheiset käännössukunimet sopivat hyvin venäläiseen nimisysteemiin, sillä ne ovat tavallisia myös venäjänkielisellä väestöllä. Toisaalta tästä syystä nimen mahdollinen karjalainen alkuperä voidaan saada selville vain nimenkantajia haastattelemalla. Tällainen tutkimusmenetelmä on varsin työläs, minkä vuoksi Karlovan kenttäretkillään keräämä aineisto on pienehkö ( 35 nimeä). Kuten hän itsekin toteaa, havaintojen vahvistaminen vaatisi lisätutkimusta.

Evar Saar tutkii artikkelissaan 1500- ja 1600-lukujen Etelä-Viron etunimistöä. Tutkimuksen kohteena oleva alue on historian aikana vaihtanut omistajaa useita kertoja, mikä on jättänyt jälkensä nimistöön mutta tekee toisaalta aineistojen hajanaisuuden myötä tutkimuksesta työlästä. Saarin esitys pohjaa puolalaisiin ja ruotsalaisiin lähteisiin sekä kirkonkirjoihin, ja joukossa on sekä aiemmin tutkittua että uutta aineistoa.

Yleisimpiä nimiä Saarin aineistossa ovat kristillisten nimien alasaksalaiset muodot, mutta myös muiden itämerensuomalaisten kielten kanssa vertailukelpoisia esikristillisiä nimiä esiintyy runsaasti. Yllättävän yleisiä ovat kirjoittajan mukaan ortodoksisen lähetystyön mukanaan tuomat venäläiset nimet. Aineistosta löytyy myös nimiä, joissa itämerensuomalaiset sekä kirjureiden käyttämien kielten ainekset sekoittuvat. Saar käsittelee artikkelissa sekä vakiintuneita että uusia selityksiä nimimuodoille.

Saar esittelee nimimateriaalia taulukoiden avulla, mikä havainnollistaa erikielisten nimimuotojen kirjavuutta. Vaikka kokonaiskuvan muodostaminen laajasta historiallisesta 
aineistosta on hankalaa, Saar onnistuu tuomaan selkeästi ja moninaisiin lähteisiin pohjaten esille keskeiset päätelmänsä tarkasteltavan historiallisen nimistön kehityksestä.

\section{Kaukaisempien sukukielten nimet}

Teoksen kolmessa viimeisessä artikkelissa siirrytään itämerensuomalaisista kielistä muihin suomalais-ugrilaisiin kieliin. Taarna Valtonen (Anthroponyms in the Saami languages) luo yleiskuvan saamelaisen ja Alexander Pustyakov (Mari personal names: history and current developments) marilaisen henkilönnimistön kehityksestä ja yleispiirteistä. Valéria Tóth (The history of the Hungarian personal name system in the context of cognitive-pragmatic description) taas tarkastelee unkarilaisten henkilönnimien historiaa.

Taarna Valtosen artikkelin tavoitteena on luoda yleiskuva saamelaisten henkilönnimistöstä ja sen tutkimusperinteestä. Tämä on monella tapaa haastava ja siksi arvokas tehtävä. Vaikka monet tutkijat jo 1600-luvulta lähtien ovat tehneet havaintoja aiheesta, tiedot ovat pitkälti fragmentaarisia, muita aiheita käsittelevien tutkimusten sivujuonteita. Kaikki tutkijat eivät myöskään ole tunteneet saamelaiskulttuuria erityisen hyvin, joten lähteisiin on suhtauduttava kriittisesti. Lisäksi maantieteellisesti laajan, kymmenen eri kieltä sisältävän saamelaisalueen henkilönnimistössä on runsaasti variaatiota. Valtonen keskittyykin etupäässä kolmeen Suomessa puhuttavaan saamen kieleen, pohjois-, koltan- ja inarinsaameen.

Valtonen aloittaa esittelemällä saamelaisten henkilönnimisysteemin yleispiirteitä nostaen esiin muun muassa patronyymit ja matronyymit, lempinimet, deminutiivimuotojen käytön sekä sukulaisuuteen perustuvan samannimisyyden. Tämän jälkeen hän käy läpi sukunimien historiaa ja etymologiaa. Paljolti keskusteltuun kysymykseen siitä, kuinka kauan saamelaisilla on ollut sukunimiä, Valtonen ei pyri löytämään selvää vastausta - vanhoista asiakirjoista sukunimet puuttuvat luultavasti siksi, että viranomaiset eivät ole vaivautuneet kirjaamaan omasta näkökulmastaan "outoja" nimiä. Lopuksi Valtonen käsittelee lyhyesti saamelaisnimistön nykytilaa ja tulevaisuutta. 1900-luvulla vanhat nimeämisperinteet alkoivat väistyä ympäröivistä kulttuureista tulleiden vaikutteiden tieltä, mutta 2000-luvulla kiinnostus perinteisiä saamelaisnimiä kohtaan on alkanut jälleen kasvaa.

Alexander Pustyakovin artikkeli kuvaa marien henkilönnimijärjestelmän muotoutumista, kehitystä ja nykytilaa. Aiheesta on tehty joitakin aiempia tutkimuksia, mutta Pustyakov osoittaa niissä puutteita, joilla hän perustee käsillä olevan tutkimuksen tarpeellisuuden.

Marien perinteessä uskotaan, että nimellä voi olla suuri vaikutus lapsen tulevaisuuteen. Niinpä monet lapset on nimetty jotakin toivottua ominaisuutta, kuten vahvuutta, rikkautta tai ystävällisyyttä ilmaisevilla sanoilla. Tältä osin marien nimeämiskulttuuri muistuttaa enemmän Kaukoidän kuin länsimaiden kulttuureita. Nimen tärkeyttä kuvastavat myös perinteikkäät nimenantoon tai -vaihtoon liittyvät juhlalliset rituaalit, jotka ovat paikoitellen säilyneet pitkään 1900-luvulle saakka.

Pustyakov ryhmittelee marien omaperäiset henkilönnimet sekä rakenteen että nimenantoperusteiden mukaan. Nimenantoperusteista tyypillisimpiä ovat eläinten ja kasvien nimitykset, sanat 'poika, 'tyttö' tai 'lapsi', lapsen tulevaisuutta ennustavat nimet, lapsen ominaisuutta kuvaavat nimet sekä syntymäajankohtaa tai -olosuhteita kuvaavat nimet. Nimiperinteeseen kuuluu vahvasti myös sukuyhteyden ilmaiseminen - jotkin nimielementit ovat säilyneet useiden sukupolvien ajan. 
Marien henkilönnimistön kehitykseen ovat vaikuttaneet kontaktit etenkin tataarien ja tsuvassien kanssa. Kontaktit ovat myös tuottaneet eroja eri alueilla asuvien marien nimien välille. Nykyistä nimistöä hallitsevat venäläisperäiset nimet. Havaittavissa on kuitenkin myös halua palauttaa marien perinteistä nimistöä käyttöön.

Valéria Tóthin artikkeli käsittelee unkarilaisten henkilönnimien historiaa kognitiivis-pragmaattisessa viitekehyksessä. Tóth aloittaa jakamalla nimet ylipäänsä yhtäältä pragmaattisesta ja toisaalta kognitiivisesta näkökulmasta eri kategorioihin, joiden lisäksi hän erottaa vielä sekundaarisen kategorian affektiiviset nimet. Tóthin teoreettinen ja metodologinen viitekehys tarkoittaa käytännössä unkarilaisten nimien luokittelua näihin kategorioihin.

Tóthin mukaan tarkoitettaan kuvaavat deskriptiiviset nimet muodostavat unkarilaisen henkilönnimistön selkärangan: niitä on ollut käytössä kaikkina aikoina, joilta kirjallisia lähteitä on olemassa, eli ainakin 900-1000-luvuilta lähtien. Referentiaaliset nimet, joiden tarkoituksena on vain viitata tiettyyn henkilöön eikä kuvailla tätä, taas ovat lainanimiä. Vanhimmat näistä ovat turkkilaisperäisiä, mutta unkarilaisten asetuttua nykyisille asuinalueilleen unkariin tuli myös slaavilaista ja germaanista henkilönnimistöä. Sekä vanhat unkarilaiset deskriptiiviset nimet että lainanimet väistyivät kristillisten nimien tieltä unkarilaisten kääntyessä kristinuskoon 900-1000-luvuilla. Kristillisten nimien yleistyessä ihmiset saivat kuitenkin deskriptiivisiä lisänimiä, jotka muistuttivat monin tavoin sukunimiä. Sukunimien käyttö taas levisi Unkarissa 1200-1600-luvuilla ja tuli pakolliseksi 1700-luvun puolivälissä.

Affektiiviset nimet jäävät artikkelissa hieman irrallisiksi. Toisaalta kirjoittaja itsekin huomauttaa, että historiallisten affektiivisten nimien tutkiminen on lähes mahdotonta, koska ei voida varmasti tietää, onko nimellä affektiivista funktiota. Tóth antaa kuitenkin muutaman esimerkin mahdollisista affektiivisista nimistä. Ilmeisesti affektiiviset nimet on otettu mukaan artikkeliin siksi, että ne täydentävät pragmaattis-kognitiivisen mallin, jonka esittely nousee artikkelin toiseksi päätarkoitukseksi unkarilaisen henkilönnimijärjestelmän esittelyn lisäksi. Tóthin artikkeli etenee johdonmukaisesti, joskin rakennetta olisi selkeyttänyt artikkelin jakaminen alalukuihin.

\section{Lopuksi}

Artikkelikokoelma tarjoaa runsaan ja monipuolisen kattauksen ajantasaista perustutkimusta suomalais-ugrilaisista henkilönnimisysteemeistä. Pääpaino on itämerensuomalaisissa kielissä, mutta myös kaukaisempia sukukieliämme on huomioitu. Vaikka teos ei muodostakaan selvää kokonaiskuvaa suomalais-ugrilaisten kielten historiallisesta nimenannosta yleisesti, johdannossa mainittu tavoite korjata eräänlaista aukkoa ja pysähtyneisyyden tilaa alalla täyttyy erinomaisesti.

Tutkimuksissa on käytetty runsaasti erilaisia menetelmiä, aineistoja ja näkökulmia. Myös artikkelien laajuudet vaihtelevat 18 sivusta 54 sivuun. Artikkelien taso on kauttaaltaan korkea, joskin tarkkaavaista lukijaa saattavat jäädä vaivaamaan joidenkin artikkelien huolimattomuusvirheet. Kokonaisuutena teos on kuitenkin laadukas, monipuolinen ja myös varsin tasapainoinen.

Kokoelman englanninkielisyys avaa artikkelikokoelman kansainväliselle lukijakunnalle ja on siksi toimiva valinta. Sen vuoksi tuntuu hieman erikoiselta, että joukossa on yksi suomenkielinen artikkeli (Karlovan). Ilahduttavaa sen sijaan on se, että abstraktit on kirjoitettu englannin 
lisäksi suomeksi tai muulla artikkelin aiheen kannalta relevantilla kielellä, kuten karjalaksi, saameksi tai unkariksi. Kaikkiaan Personal name systems in Finnic and beyond on erittäin tervetullut lisä suomalais-ugrilaisen nimistöntutkimuksen alalle.

\section{Maria SarhemaA, LASSE HämäLÄINEN JA VÄINÖ SyrJälä}

Maria Sarhemaa maria.sarhemaa@helsinki.fi

Debreceni Egyetem

Finnugor Nyelvtudományi Tanszék

Pf. 400
Lasse Hämäläinen lasse.j.hamalainen@helsinki.fi Viulutie 7 B 23 o0420 Helsinki 00014 Helsingin yliopisto vaino.syrjala@helsinki.fi Nordica PL 24
Väinö Syrjälä 4002 Debrecen, Unkari 